\title{
Studies on the frozen stored buffalo meat sausages incorporating offal meat under different packaging conditions
}

\author{
D. Muthulakshmi ${ }^{a}$, K. Dushyanthan, ${ }^{\text {b }}$ (D) R. Narendra Babu ${ }^{c}$ and (D) C. Vasanthi ${ }^{d}$
}

${ }^{a}$ Assistant Professor, Department of Livestock Products Technology (Meat Science), Veterinary College and Research Institute, Namakkal, TANUVAS

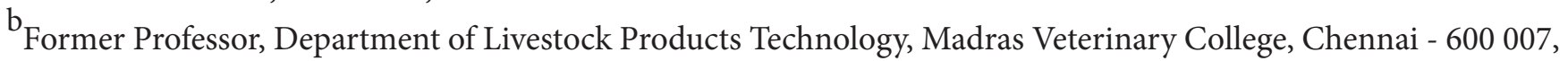
Tamil Nadu, India.

${ }^{c}$ Professor and Head, Department of Livestock Products Technology, Madras Veterinary College, Chennai - 600 007, Tamil Nadu, India.

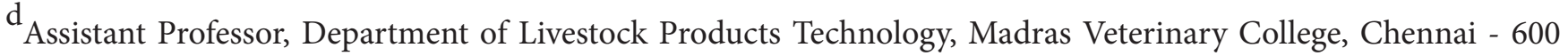
007, Tamil Nadu, India.

Corresponding author: M. Muthulakshmi | email: muthulakshmivet@gmail.com Co-author: KD: karmegamdushyanthan@gmail.com, RNB: nbabu.ravindran@gmail.com,

CV: vasivet@yahoo.co.in

Received: 09-10-2020, Accepted: 28-11-2020, Published online: 20-12-2020

\begin{abstract}
The effect of different packaging methods on the shelf life of buffalo meat sausages Stored at $-18 \pm 1^{\circ} \mathrm{C}$ was studied. Two type of sausage were prepared as control (skeletal meat only) and treatment (skeletal meat plus offal meat incorporated). The sausages were stored at $-18 \pm 1^{\circ} \mathrm{C}$ up to 60 days by aerobic and vacuum packaging conditions. No significant difference in colour and shear force values was observed between packaging methods. Vacuum packed sausages had higher $\mathrm{pH}$ and also recorded lower thiobarbituric acid number, tyrosine value and total viable count. During storage at $-18 \pm 1^{\circ} \mathrm{C}$ decreasing trends of microbial count were noticed. Sensory scores gradually decreased during storage periods. Based on the findings, it was concluded that the offal meat incorporated buffalo meat sausages could be stored up to 60 th day by aerobic and vacuum packaging conditions at $-18 \pm 1^{\circ} \mathrm{C}$ without any appreciable deterioration in the quality and acceptability of the product.
\end{abstract}

Keywords: Buffalo meat, sausages, offal meat, packaging methods, Shelf-life

doi: https://doi.org/10.51128/jfas.2020.A019 | How to cite this article: Muthulakshmi, M., Dushyanthan, K., Babu, R. N., and Vasanthi, C., 2020. Studies on the frozen stored buffalo meat sausages incorporating offal meat under different packaging conditions. Journal of Food and Animal Sciences, 01(02): 104 - 111.

Copyright: Muthulakshmi et al., 2020. Open Access. This article is distributed under the terms of the Creative Commons Attribution 4.0 International License (http://creativecommons.org/licenses/by/4.0/), which permits unrestricted use, distribution, and reproduction in any medium, provided you give appropriate credit to the original author(s) and the source, provide a link to the Creative Commons license, and indicate if changes were made. The Creative Commons Public Domain Dedication waiver (http://creativecommons.org/publicdomain/zero/1.0/) applies to the data made available in this article, unless otherwise stated. 


\section{Introduction}

Meat and meat products play a vital role in sustaining human life. It provides valuable animal protein for human utility. Buffalo meat has several good attributes such as high protein, low fat and cholesterol as well as low calories in comparison to beef. It has good functional properties for processing into a variety of meat products (Murthy and Devadason, 2003; Irshad et al., 2016). There is an increased in demand to utilize different low value cuts and edible by-products gainfully. Due to rapid urbanization, increase in the number of working women folks, lack of time for cooking and less preference to traditional meat products at home there is an increase in demand for processed value added meat products. Processed meat needs protection from bacteriological contamination, oxidation, dehydration, discolouration and loss of aroma and is to ensure the quality of product until to consumers (Mondry, 1996). Packaging enhances the product appeal to the consumer and facilitates easy distribution, storage and marketing of meat products. Due to globalization and to withstand the competition, there is a need for Indian meat industry to adopt newer packaging technologies like vacuum and modified atmosphere packaging. Removal of air from the package is called vacuum packaging. Vacuum packaging can prevent the growth of some food borne pathogens and spoilage bacteria commonly present on meat (Parra et al., 2010).

Hence, with the above information it has been contemplated to study the effect of different packaging methods on the shelf life of buffalo meat sausage incorporating offal meat.

\section{Materials and Methods}

A total 12 batches of buffalo meat sausages were prepared in this study. Out of this, six batches were prepared with inclusion of skeletal meat alone (control) and another six batches with offal meat (treatment). These sausages were packed in polyester polyethylene (Pet/poly) pouches by different methods like Aerobic Packaging (AP) and Vacuum Packaging (VP). The sausages were subjected to physico-chemical, sensory, and microbiological quality evaluation during storage at $-18 \pm 1{ }^{\circ} \mathrm{C}$ on $30^{\text {th }}$ and $60^{\text {th }}$ day to determine the suitable packaging method for buffalo meat sausages.

\section{Buffalo meat sausages Formulation}

Table 1: Formulation of buffalo meat sausages per $\mathrm{kg}$

\begin{tabular}{|c|c|c|}
\hline Ingredients & Control & Treatment \\
\hline Buffalo lean meat & $900 \mathrm{~g}$ & $670 \mathrm{~g}$ \\
\hline Cheek meat & - & $112.5 \mathrm{~g}$ \\
\hline Tongue & - & $56.25 \mathrm{~g}$ \\
\hline Heart & - & $56.25 \mathrm{~g}$ \\
\hline Buffalo fat & $50 \mathrm{~g}$ & $50 \mathrm{~g}$ \\
\hline Sunflower oil & $50 \mathrm{~g}$ & $50 \mathrm{~g}$ \\
\hline Binder & $50 \mathrm{~g}$ & $70 \mathrm{~g}$ \\
\hline Salt & $15 \mathrm{~g}$ & $15 \mathrm{~g}$ \\
\hline Ice & $100 \mathrm{~g}$ & $100 \mathrm{~g}$ \\
\hline Dry Spice $\operatorname{mix}^{*}$ & $18 \mathrm{~g}$ & $18 \mathrm{~g}$ \\
\hline $\begin{array}{ll}\text { Green spice mix: } \\
\text { Onion } & -30 \mathrm{~g} \\
\text { Garlic } & -10 \mathrm{~g}\end{array}$ & $40 \mathrm{~g}$ & $40 \mathrm{~g}$ \\
\hline Sodium nitrite & $0.1 \mathrm{~g}$ & $0.1 \mathrm{~g}$ \\
\hline $\begin{array}{l}\text { Sodium } \\
\text { tripolyphosphate }\end{array}$ & $3 g$ & $3 g$ \\
\hline
\end{tabular}

Buffalo lean meat, cheek meat, heart, tongue and fat were obtained from the buffaloes slaughtered at the Chennai Corporation Slaughterhouse, Perambur, packed individually in clean polyethylene bags and quickly chilled in a thermocole box to the Department of Meat Science and Technology, Madras Veterinary College, Chennai-7. Excess connective tissue, cartilage and bone from meat and offal were trimmed off and chopped into pieces. The chopped pieces were then packed separately in clean polyethylene bags and stored at $-20^{\circ} \mathrm{C}$ until used. Plain flour (maida) at the level of five per cent was used for control and at the level of seven per cent was used in the formulation incorporating offal meat sausage as treatment. The spice mix formulation (per cent $\mathrm{W} / \mathrm{W}$ ) used in this study was coriander powder-20, anise-15, black pepper-13, red chillies -15 , cumin -10 , dried ginger-10, cinnamon-5, cloves-5, turmeric-5 and cardamom- 2 . The ground spices were stored at room temperature $\left(35 \pm 2^{\circ} \mathrm{C}\right)$ until used and at 1.8 per cent added. Cleaned and chopped onion and garlic in the ration 3: 1 was used in the formulation and was added at 4 per cent level. Curing ingredients like sodium nitrite - 0.012 per cent, sodium tripolyphosphate -0.3 per cent and salt - 1.5 per cent were also added. Water in the form 
of slushed ice at 10 per cent level was added.

\section{Preparation of Buffalo Meat Sausage}

In the formulation meat was included at 90 per cent level and fat at 10 per cent level. The control samples contained only the lean meat. While in treatment, 25 per cent of the meat was replaced by offal, viz., cheek, heart and tongue in the ratio 50:25:25. Of the 10 per cent fat component, 5 per cent was buffalo fat and the rest sunflower oil.

The frozen lean meat, cheek meat, heart, tongue and fat were cut into chunks of $4-6 \mathrm{~cm}$ thickness, weighed and minced separately using $4.5 \mathrm{~mm}$ plate in a meat mincer (Omas, Model No. 169789, Electrolux Food Service, Italy). The minced meat and fat were then chopped in bowl chopper (Mado MTK 662, Maschinen Fabric., Germany) using three blade cutter. The emulsion was prepared by adding minced meat and other ingredients of recipe in a sequential order at a specified time interval. The specified quantities of salt, sodium tripolyphosphate and sodium nitrite were premixed and added to the meat mix. Sunflower oil was cooled to $4^{\circ} \mathrm{C}$ before it is added to the mixture. During chopping, the temperature of the emulsion was maintained at $10-12^{\circ} \mathrm{C}$ by the addition of slushed ice of the specified quantity. Identical procedure was followed, for different treatments. About $3 \mathrm{~kg}$ of emulsion was prepared for each treatment. The emulsion was stuffed into 10-20 mm diameter sheep casings using sausage stuffer (Mado MWF 591, Maschinnen Fabric., Germany). The stuffed sausages were then interlinked and hanged from smoke sticks.

\section{Smoking and Cooking of Sausage}

Linked sausages were smoked for one hour in smoke house (KERRIS, SHOW SMOKER CS 350 "G" EL Maxi 1001) at $65^{\circ} \mathrm{C}$ and then cooked by steam cooking for $15 \mathrm{~min}$ at $80{ }^{\circ} \mathrm{C}$. The temperature and time of smoking and cooking was programmed in the smoke chamber, so that internal temperature of 72 ${ }^{\circ} \mathrm{C}$ was reached in the product. Smoke was generated using hard wood sawdust (Hickory) soaked in water at the ratio of $3: 1$.

\section{Packaging}

Cooked sausages were allowed to cool at room temperature. The sausages were cut at linking and packed in sterile Pet/Poly pouches (thickness- 62 $\mu$, oxygen transmission rate -140 to $150 \mathrm{cc} . / \mathrm{sq} . \mathrm{m} / 24$ hrs/atmosphere) under aerobic and vacuum. Aerobic and vacuum packed samples were stored at $-18 \pm 1^{\circ} \mathrm{C}$ and analysed on $30^{\text {th }}$ and $60^{\text {th }}$ day. The samples were subjected to physico-chemical, microbiological quality studies.

\section{Physico-Chemical Characteristics}

\section{Colour}

The colour of the cooked samples was measured with a Hunterlab Miniscan XE Plus Spectrophotometer (Hunterlab, Virginia, USA). The instrument was set to measure CIE $\mathrm{L}^{*}, \mathrm{a}^{*}, \mathrm{~b}^{*}$ and it was calibrated using white and black standard plates.

\section{pH}

The $\mathrm{pH}$ of the sausage was measured using a digital $\mathrm{pH}$ meter (Cyberscan pH510, Merck, Germany). About five grams of sample was homogenized with $45 \mathrm{ml}$ of distilled water in a laboratory blender for about one minute. The $\mathrm{pH}$ was recorded by immersing the combined glass electrode of digital $\mathrm{pH}$ meter in the homogenate.

\section{Shear Force Value}

The shear force values of cooked sausages were assessed at three different points using Warner Bratzler shear press (Model no. 04347, The G.R MFG. Co., Manhattan, USA) as per method of Rao et al. (1999) and expressed as in $\mathrm{kg} / \mathrm{cm}^{2}$.

\section{Thiobarbituric Acid Number}

Thiobarbituric acid (TBA) number was measured by a modified method by Strange et al. (1977).

\section{Tyrosine value}

Tyrosine value was determined by the modified method of Strange et al. (1977).

\section{Microbiological Qualities}

For microbial analysis a representative $5 \mathrm{~g}$ of samples was triturated aseptically in a pestle and mortar with $45 \mathrm{ml}$ of 0.1 per cent sterile peptone water and serial dilutions were made using 0.1 per cent sterile peptone water. The total viable counts (TVC) were enumerated on duplicate pour plates of 
plate count agar which were incubated at $37^{\circ} \mathrm{C}$ for 48 hours. Psychrophilic count (PC) on pour plates of plate count agar which were incubated at $4 \pm 1^{\circ} \mathrm{C}$ for $10-14$ days; anaerobic bacterial counts (AC) on pour plates of anaerobic plate count agar which were incubated at $43^{\circ} \mathrm{C}$ for 48 hours and yeast and mould counts (YM) on pour plates of Sabouraud dextrose agar was used which were incubated at $30 \mathrm{C}$ for 48 hours. Colonies were counted and expressed as $\log _{10} \mathrm{cfu} / \mathrm{g}$ of sample (APHA, 1984). All the media used were of Himedia, Mumbai.

\section{Statistical Analysis}

The data obtained in this study were analysed statistically as per the method out lined by Snedecor and Cochran (1994).

\section{Results and Discussion}

\section{Physico-Chemical Characteristics}

The mean of Hunter colour $\mathrm{L}^{*}, \mathrm{a}^{*}, \mathrm{~b}^{*}$ values of control and treated sausages on the day of production were $31.19 \pm 0.52$ and $30.58 \pm 0.71 ; 15.46 \pm 1.09$ and $13.52 \pm 0.04 ; 10.71 \pm 0.67$ and $8.76 \pm 0.57$, respectively. The lowest $L^{*}, a^{*}, b^{*}$ value was observed in sausages with offal on the 0 day. In frozen storage, there was significant $(\mathrm{P}<0.05)$ difference between treatments and storage days for $\mathrm{L}^{*}$ value and $\mathrm{b}^{*}$ value and also between method and storage days for $b^{*}$ value.

The overall mean \pm SE of $L^{*}$ value of sausages packed under AP and VP methods were 34.76 \pm 0.87 and 33.95 \pm 0.62 , respectively with no significant ( $P>0.05$ ) difference between the methods of packaging as observed by Rubio et al., (2006). The overall mean \pm SE of Hunter colour $L^{*}$ value of packed sausages stored on 0,30 and 60 days were $30.88 \pm 0.30,33.44 \pm 0.37$ and $38.75 \pm 1.00$, respectively with significant $(\mathrm{P}<0.05)$ difference between the storage days. The over all mean $\pm \mathrm{SE}$ of $\mathrm{L}^{*}$ value of control and treated sausages were $35.51 \pm 0.86$ and $33.19 \pm 0.58$, respectively with significant $(\mathrm{P}<0.05)$ difference was revealed between the two treatments.

The overall mean \pm SE of $\mathrm{a}^{*}$ value of sausages packed under AP and VP methods were 14.63 \pm 0.29 and $14.42 \pm 0.31$, respectively, discerning no significant ( $P>0.05)$ difference between the methods of packaging as observed by Rubio et al., (2006). The overall mean \pm SE of $a^{*}$ value of packed sausages stored on 0,30 and 60 days were $14.49 \pm 0.54,14.88 \pm 0.22$ and $14.22 \pm 0.27$, respectively and also heeding no significant $(\mathrm{P}>0.05)$ difference between the storage days was contrary to Garcia-Esteban et al.,(2004). The over all mean \pm SE of Hunter colour $\mathrm{a}^{*}$ value of control and treated sausages were $14.95 \pm 0.30$ and $14.11 \pm 0.29$, respectively with significant $(\mathrm{P}<0.05)$ difference between the treatments.

The overall mean \pm SE of $b^{*}$ values of sausages packed under AP and VP methods were 13.14 \pm 0.46 and $13.21 \pm 0.47$, respectively discerning no significant ( $P>0.05)$ difference between the methods of packaging as observed by Rubio et al., (2006). The overall mean \pm SE of $b^{*}$ values of packed sausages stored on 0,30 and 60 days were $9.73 \pm 0.36,15.10 \pm 0.24$, and $14.68 \pm 0.19$, respectively with significant $(\mathrm{P}<0.05)$ difference between the storage days (Garcia-Esteban et al.,(2004). The over all mean \pm SE of $b^{*}$ values of control and treated sausages were $13.55 \pm 0.40$ and $12.81 \pm 0.52$, respectively with significant $(\mathrm{P}<0.05)$ difference between the treatments.

Table -2: $\mathrm{pH}($ Mean $\pm \mathrm{SE})$ of buffalo meat sausages stored at $-18 \pm 1^{\circ} \mathrm{C}$

\begin{tabular}{|c|l|c|c|c|}
\hline \multicolumn{2}{|c|}{ TRs and PMs } & \multicolumn{3}{c|}{ Storage Period in Days } \\
\cline { 3 - 5 } \multirow{2}{*}{ AP } & Control & $6.49 \pm 0.08$ & $\mathbf{3 0}$ & 60 \\
\cline { 2 - 5 } & Treated & $6.63 \pm 0.11$ & $5.90 \pm 0.04$ & $5.87 \pm 0.04$ \\
\cline { 2 - 5 } & Means of methods in days & $6.56^{\mathrm{a}} \pm 0.02$ & $6.04 \pm 0.02$ & $5.94 \pm 0.03$ \\
\hline \multirow{2}{*}{ VP } & Control & $6.49 \pm 0.08$ & $5.97^{\mathrm{b}} \pm 0.01$ & $5.90^{\mathrm{b}} \pm 0.01$ \\
\cline { 2 - 5 } & Treated & $6.63 \pm 0.11$ & $6.12 \pm 0.03$ & $6.07 \pm 0.02$ \\
\cline { 2 - 5 } & Means of methods in days & $6.56^{\mathrm{a}} \pm 0.02$ & $6.18 \pm 0.01$ & $6.11 \pm 0.01$ \\
\hline
\end{tabular}

Means bearing uncommon superscripts differ $(\mathrm{P}<0.05)$ significantly 
Table. 3: TBA Number (Mean \pm SE) of buffalo meat sausages stored at $-18 \pm 1^{\circ} \mathrm{C}$

\begin{tabular}{|c|c|c|c|c|}
\hline \multirow{2}{*}{\multicolumn{2}{|c|}{ TRs and PMs }} & \multicolumn{3}{|c|}{ Storage Period in Days } \\
\hline & & \multirow{2}{*}{$\begin{array}{c}\mathbf{0} \\
0.04 \pm 0.00\end{array}$} & \multirow{2}{*}{$\begin{array}{c}30 \\
0.22 \pm 0.00 \\
\end{array}$} & \multirow{2}{*}{$\begin{array}{c}60 \\
0.29 \pm 0.01\end{array}$} \\
\hline $\mathrm{AP}$ & Control & & & \\
\hline & Treated & $0.03 \pm 0.00$ & $0.20 \pm 0.02$ & $0.24 \pm 0.02$ \\
\hline & Means of methods in days & $0.03^{\mathrm{a}} \pm 0.00$ & $0.21^{\mathrm{b}} \pm 0.01$ & $0.27^{c} \pm 0.02$ \\
\hline \multirow[t]{3}{*}{ VP } & Control & $0.04 \pm 0.00$ & $0.16 \pm 0.00$ & $0.21 \pm 0.01$ \\
\hline & Treated & $0.03 \pm 0.00$ & $0.12 \pm 0.00$ & $0.21 \pm 0.01$ \\
\hline & Means of methods in days & $0.03^{\mathrm{a}} \pm 0.00$ & $0.14^{\mathrm{b}} \pm 0.01$ & $0.21^{\mathrm{c}} \pm 0.01$ \\
\hline
\end{tabular}

Means bearing uncommon superscripts differ $(\mathrm{P}<0.05)$ significantly

Significant $(\mathrm{P}<0.05)$ difference was divulged between the methods of packaging. Sausages packed under vacuum had the highest $\mathrm{pH}$ when compared to other packaging method. Significant $(\mathrm{P}<0.05)$ difference was observed between storage days as observed by Anand et al., 1991. There was significant $(\mathrm{P}<0.05)$ difference observed between treatments and treated sausages recorded higher $\mathrm{pH}$ than control sausages.

No significant $(\mathrm{P}>0.05)$ difference was divulged between the methods of packaging which was in agreement with the finding of Rajkumar et al.,2004 and Dharmaveer et al., 2007. Also no significant $(\mathrm{P}>0.05)$ difference between the storage days. Storage period did not significantly affect the hardness (shear force value) of the product.

Significant $(\mathrm{P}<0.05)$ difference was divulged between storage days (Anand et al., 1991 and Prabhakara Reddy et al., 2004) and also between the methods of packaging. Significant $(\mathrm{P}<0.05)$ difference was divulged between treatments and control sausages recorded lower TBA number than treated sausages.

Significant $(\mathrm{P}<0.05)$ difference was observed between the two methods of packaging. Vacuum packed sausages had the lowest tyrosine value. On analysis of variance between the storage days a significant $(\mathrm{P}<0.05)$ difference was perceived. Sausages kept on the 0 day had the lowest TV.

\section{Microbial qualities}

No significant $(P>0.05)$ was noticed between the two methods of packaging for TVC. Lower TVC was found in sausages packed under vacuum. Significant $(\mathrm{P}<0.05)$ difference was observed between the storage periods on analysis of variance. The lowest TVC was reported in sausages kept on the $60^{\text {th }}$ day. Anand et al., 1991 observed similar findings Significant $(\mathrm{P}<0.05)$ difference was noticed between the two treatments, treated sausage had lowest TVC. The

Table. 4: Mean $( \pm \mathrm{SE})$ of Tyrosine value $(\mathrm{mg} / 100 \mathrm{~g})$ of sausages stored at $-18 \pm 1^{\circ} \mathrm{C}$

\begin{tabular}{|c|c|c|c|c|}
\hline \multirow{2}{*}{\multicolumn{2}{|c|}{ TRs and PMs }} & \multicolumn{3}{|c|}{ Storage Period in Days } \\
\hline & & \multirow{2}{*}{$\begin{array}{c}\mathbf{0} \\
1.22 \pm 0.01\end{array}$} & \multirow{2}{*}{$\begin{array}{c}30 \\
3.14 \pm 0.00\end{array}$} & \multirow{2}{*}{$\begin{array}{c}60 \\
3.01 \pm 0.02\end{array}$} \\
\hline $\mathrm{AP}$ & Control & & & \\
\hline & Treated & $1.13 \pm 0.01$ & $2.85 \pm 0.01$ & $3.42 \pm 0.00$ \\
\hline & Means of methods in days & $1.17^{\mathrm{a}} \pm 0.07$ & $3.00^{\mathrm{b}} \pm 0.06$ & $3.22^{c} \pm 0.09$ \\
\hline \multirow[t]{3}{*}{ VP } & Control & $1.22 \pm 0.01$ & $2.95 \pm 0.00$ & $3.03 \pm 0.00$ \\
\hline & Treated & $1.13 \pm 0.01$ & $2.63 \pm 0.00$ & $3.03 \pm 0.00$ \\
\hline & Means of methods in days & $1.17^{\mathrm{a}} \pm 0.07$ & $2.79^{b} \pm 0.05$ & $3.03^{c} \pm 0.04$ \\
\hline
\end{tabular}

Means bearing uncommon superscripts differ $(\mathrm{P}<0.05)$ significantly 


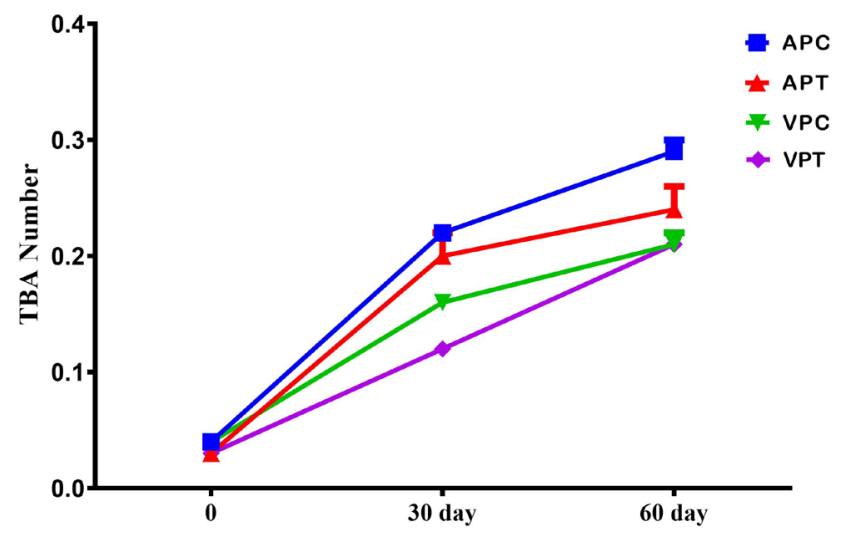

Figure 1: TBA Number (Mean \pm SE) of buffalo meat sausages stored at $-18 \pm 1^{\circ} \mathrm{C}$

lowest $\mathrm{AC}$ were recognized in sausages packed under aerobic method and stored upto 60 days of storage good microbial quality with increased in storage periods. No significant $(\mathrm{P}>0.05)$ difference was divulged between the two methods of packaging for YM. Sausages packed under aerobic revealed the lowest YM count. The analysis of variance between the storage days exposed a significant $(\mathrm{P}<0.05)$ difference. Sausages kept on the $60^{\text {th }}$ day registered the lowest YM count. There was decrease in count with increased storage period as observed by Anand et al. 1991. Significant $(\mathrm{P}<0.05)$ was noticed between the two treatments. Control sausage had lower YM count.

No psychrophilic organisms could be detected in any of the samples during the entire period of storage under different packaging methods.

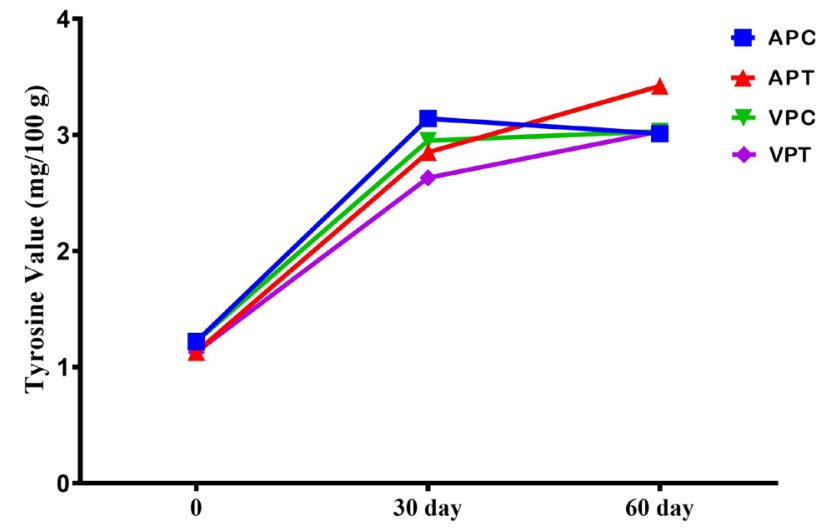

Figure 2: Tyrosine value (mg/100 g) (Mean \pm SE) of buffalo meat sausages stored at $-18 \pm 1^{\circ} \mathrm{C}$

\section{Conclusions}

Based on the above findings, it is concluded that the offal meat incorporated buffalo meat sausages could be stored up to $60^{\text {th }}$ day by aerobic and vacuum packaging at $-18 \pm 1^{\circ} \mathrm{C}$ without any appreciable deterioration in the quality and acceptability of the product.

\section{Authorship contribution statement}

M. Muthulakshmi : Conceptualization, Writing - original draft, Writing - review \& editing, K. Dushyanthan : Writing - review \& editing;

R. Narendra Babu : Conceptualization, Writing review

C. Vasanthi : Writing - review

Table -5 Mean $( \pm \mathrm{SE})$ of total viable count $(\log \mathrm{cfu} / \mathrm{g})$ of sausages stored at $-18 \pm 1^{\circ} \mathrm{C}$

\begin{tabular}{|l|l|c|c|c|}
\hline \multicolumn{2}{|c|}{ TRs and PMs } & \multicolumn{3}{c|}{ Storage Period in Days } \\
\cline { 3 - 5 } \multicolumn{2}{|c|}{} & $\mathbf{0}$ & $\mathbf{3 0}$ & 60 \\
\hline \multirow{3}{*}{ AP } & Control & $3.14 \pm 0.02$ & $2.98 \pm 0.02$ & $2.56 \pm 0.07$ \\
\cline { 2 - 5 } & Treated & $3.15 \pm 0.02$ & $2.98 \pm 0.02$ & $2.38 \pm 0.08$ \\
\cline { 2 - 5 } & Means of methods in days & $3.14^{\mathrm{a}} \pm 0.01$ & $2.98^{\mathrm{b}} \pm 0.01$ & $2.46^{\mathrm{c}} \pm 0.06$ \\
\hline \multirow{3}{*}{ VP } & Control & $3.14 \pm 0.02$ & $2.97 \pm 0.03$ & $2.39 \pm 0.09$ \\
\cline { 2 - 5 } & Treated & $3.15 \pm 0.02$ & $2.86 \pm 0.05$ & $2.37 \pm 0.02$ \\
\cline { 2 - 5 } & Means of methods in days & $3.14^{\mathrm{a}} \pm 0.01$ & $2.91^{\mathrm{b}} \pm 0.03$ & $2.37^{\mathrm{c}} \pm 0.02$ \\
\hline
\end{tabular}

Means bearing uncommon superscripts differ $(\mathrm{P}<0.05)$ significantly 
Table -6 Mean $( \pm \mathrm{SE})$ of anaerobic count $(\log \mathrm{cfu} / \mathrm{g})$ of sausages stored at $-18 \pm 1^{\circ} \mathrm{C}$

\begin{tabular}{|c|c|c|c|c|}
\hline \multirow{2}{*}{\multicolumn{2}{|c|}{ TRs and PMs }} & \multicolumn{3}{|c|}{ Storage Period in Days } \\
\hline & & \multirow{2}{*}{$\begin{array}{c}\mathbf{0} \\
3.10 \pm 0.01\end{array}$} & \multirow{2}{*}{$\begin{array}{c}30 \\
3.04 \pm 0.15 \\
\end{array}$} & \multirow{2}{*}{$\begin{array}{c}60 \\
2.96 \pm 0.15 \\
\end{array}$} \\
\hline AP & Control & & & \\
\hline & Treated & $3.10 \pm 0.01$ & $3.03 \pm 0.12$ & $2.95 \pm 0.14$ \\
\hline & Means of methods in days & $3.10 \pm 0.02$ & $3.03 \mathrm{a} \pm 0.09$ & $2.96 \pm 0.10$ \\
\hline \multirow[t]{3}{*}{$\mathrm{VP}$} & Control & $3.10 \pm 0.01$ & $3.07 \pm 0.13$ & $2.99 \pm 0.13$ \\
\hline & Treated & 3. $10 \pm 0.01$ & $3.04 \pm 0.11$ & $2.92 \pm 0.09$ \\
\hline & Means of methods in days & $3.10^{\mathrm{a}} \pm 0.02$ & $3.05^{b} \pm 0.08$ & $2.95^{\mathrm{b}} \pm 0.8$ \\
\hline
\end{tabular}

Means bearing uncommon superscripts differ $(\mathrm{P}<0.05)$ significantly

Table -7 Mean $( \pm \mathrm{SE})$ of Yeast and mould count $(\log \mathrm{cfu} / \mathrm{g})$ of sausages stored at $-18 \pm 1^{\circ} \mathrm{C}$

\begin{tabular}{|c|c|c|c|c|}
\hline \multirow{2}{*}{\multicolumn{2}{|c|}{ TRs and PMs }} & \multicolumn{3}{|c|}{ Storage Period in Days } \\
\hline & & 0 & 30 & 60 \\
\hline \multirow[t]{3}{*}{$\mathrm{AP}$} & Control & $2.72 \pm 0.02$ & $2.64 \pm 0.03$ & $2.58 \pm 0.03$ \\
\hline & Treated & $2.74 \pm 0.02$ & $2.72 \pm 0.02$ & $2.70 \pm 0.02$ \\
\hline & Means of methods in days & $2.73^{\mathrm{a}} \pm 0.02$ & $2.67^{b} \pm 0.02$ & $2.64^{\mathrm{c}} \pm 0.03$ \\
\hline \multirow[t]{3}{*}{ VP } & Control & $2.72 \pm 0.02$ & $2.60 \pm 0.03$ & $2.55 \pm 0.03$ \\
\hline & Treated & $2.74 \pm 0.02$ & $2.68 \pm 0.02$ & $2.66 \pm 0.02$ \\
\hline & Means of methods in days & $2.73^{\mathrm{a}} \pm 0.02$ & $2.64^{\mathrm{b}} \pm 0.02$ & $2.61^{\mathrm{b}} \pm 0.02$ \\
\hline
\end{tabular}

Means bearing uncommon superscripts differ $(\mathrm{P}<0.05)$ significantly

\section{Acknowledgments}

All the authors acknowledge and thank their respective Institutes and Universities.

\section{Funding}

None.

\section{Declaration of Competing Interest}

All authors declare that there exist no commercial or financial relationships that could, in any way, lead to a potential conflict of interest.

\section{Reference}

Anand, S.K., N.K. Pendey, C.M. Mahapatra and S.S. Verma, 1991. Microbial quality and shelf life of chicken patties stored at $-18^{\circ} \mathrm{C}$. Indian J. Poult. Sci., 26(2): 105-108.

Dharmaveer, S., V. Rajkumar and K.P. Mukesh,
2007. Quality and shelf- life of smoked chevon sausage packed under vacuum and storage at $4 \pm 1^{\circ} \mathrm{C}$. Am. J. Food Tech., 2(4): 238-247.

Garcia-Esteban, M., D. Ansorenna and I. Astiasaran, 2004. Comparison of modified atmosphere packaging and vacuum packaging for long period storage of dry-cured ham: effects on colour, texture and microbiological quality. Meat Sci., 67: 57-63.

Irshad, A., Sharma, B. D., Ahmed, S.R., Talukder, S., Malav, O.P. and Ashish Kumar. 2016. Effect of incorporation of calcium lactate on physicochemical, textural, and sensory properties of restructured buffalo meat loaves. Veterinary World. 9(2): 151

Mondry, H., 1996. Packaging systems for processed meat. In meat quality and meat packaging. (Tylor, S.A., Rajmundo, .A., Severini, M. and Smulders, F.J.M. eds). Utrecht: ECCEA MST. III, 323.

Murthy, T.R.K. and I.P. Devadason, 2003. Buffalo meat and meat products. In proceeding of the 
$4^{\text {th }}$ Asian buffalo congress on buffalo for food security and rural employment. Feb 25-28, New Delhi India. P.194.

Parra V., Viguera J., Sanchez J., Peinado J., Esparrago F., Gutierrez J.I., Andres A.I. 2010. Modified atmosphere packaging and vacuum packaging for long period chilled storage of dry-cured Iberian ham, Meat Science 84 (4): 760-768.

Prabhakarareddy, K., Z. Naveena and P.R.S. Moorthy, 2004. Quality of emu bird (dromaeus novochollandiae) meat patties and sausages. J.Food Sci. Technol., 41(2): 188-190.

Rajkumar, V., M.K.Agnihotri, and N.Sharma, 2004.

Quality and shelf-life of vacuum and aerobic packed chevon patties under refrigeration temperature. Asian-Aust.J.Anim.Sci., 17:548-553.
Rao, K.H., A.S.R. Anja neyulu, R.R B. Singh, P.C. Duber and P.L. Yaday, 1999. Effect of whey protein concentrate on the quality of smoked chicken sa usages from broiler spent hens. Ind. J. of Anim. Sci., 69(6):441-444.

Rubio, B, B. Martinez, C. G. Fernandez, M. D. Garciacachan, J. Rovira and I. S. Jaime. 2006. Influence of storage period and packaging method on sliced dry cured beef "cecina de leon": Effect on Microbiological physico chemical and sensory quality. Meat Sci., 74(2): 710-721.

Snedecor, G.W. and W.G.Cohran,1994.Statistical methods. The Iowa State University Press, Iowa.

Strange, E.D., R.C. Benedict, J.L. Smith and L.E. Swift, 1977. Evaluation of rapid test for monitoring alteration in meat during storage. 1. Intact meat. J.Food. Prot., 40: 843-847. 